\title{
Triple X syndrome: a review of the literature
}

The developmental and clinical aspects in the literature on triple $\mathrm{X}$ syndrome are reviewed. Prenatal diagnosis depends on karyotyping. The incidence is 1 of 1000 females. At birth, 47,XXX girls have a lower mean birth weight and a smaller head circumference. Triple $X$ diagnosis was not suspected at birth. The maternal age seems to be increased. Toddlers with triple $X$ syndrome show delayed language development. The youngest girls show accelerated growth until puberty. EEG abnormalities seem to be rather common. Many girls show motor-coordination problems and auditory-processing disorders are not rare. Scoliosis is probably more common in adolescent cases. The IQ levels are 20 points below that of controls, and verbal IQ is lowest. The girls struggle with low self-esteem and they need psychological, behavioural and educational support. They perform best in stable families. After leaving school they seem to feel better. In adults, premature ovarian failure seems to be more prevalent than in controls. MRIs of the brain seem to show decreased brain volumes. The $47, \mathrm{XXX}$ women most often find jobs that reflect their performance abilities. Psychotic illness seems to be more prevalent in triple $X$ adult women than in controls. Psychotic disorders respond well to psychotropic drugs. Triple $X$ adults suffer more frequently from cyclothymic and labile personality traits. Research on triple $X$ syndrome may yield more insight into brain and behaviour relations, developmental psychopathology, auditory-processing disorders, EEG disorders, personality and psychotic disorders, etc.

In brief

- One in every 1000 females has an extra X chromosome.

- The physical phenotype shows earlier growth and longer legs.

- The behavioural phenotype often shows auditory processing disorders, disorders in language development and problems in forming stable interpersonal relationships.
- Psychiatric disorders seem to be more common in triple $\mathrm{X}$ syndrome.

- Quality of life seems to increase after leaving school.

- Further research is necessary. This is true in physical and behavioural aspects.

\section{INTRODUCTION}

Triple X syndrome $(47, \mathrm{XXX})$ is not extremely rare, although one might think so, as the majority of cases go undiagnosed. ${ }^{1}$ The incidence has been established to $1 / 1000$ females, since the earliest case series have been published and confirmed by others. ${ }^{2}$ Triple $\mathrm{X}$ syndrome is a sex chromosomal abnormality (SCA). The sex chromosomes have aneuploid counts in SCA, e.g. 47,XYY, 47,XXY, 47,XO, etc. SCA may be mosaic. ${ }^{3}$

After the description of Down's anomaly as trisomy $21,{ }^{4}$ Klinefelter syndrome as 47, $\mathrm{XXY}^{5}$ and Turner's syndrome as $45, \mathrm{XO},{ }^{6}$ the first triple X case was published. ${ }^{7}$ In 1959 , Jacobs described the first 47,XXX female, an infertile patient. A similar condition had already been described in infertile Drosophila melanogaster. ${ }^{7}$ In contrast to Down's syndrome, Klinefelter syndrome and Turner's syndrome, there were no

Maarten Otter*,1,2, Constance TRM Schrander-Stumpel ${ }^{3}$ and Leopold MG Curfs ${ }^{3}$

${ }^{1}$ Department of Child and Adolescent Psychiatry, Eleos, Amersfoort, The Netherlands; ${ }^{2}$ Department of Adult Psychiatry, Eleos, Amersfoort, The Netherlands; ${ }^{3}$ Department of Clinical Genetics, Academic Hospital Maastricht, GROW-School for Oncology and Developmental Biology, University Maastricht, Maastricht, The Netherlands

European Journal of Human Genetics (2010) 18, 265-271; doi:10.1038/ ejhg.2009.109; published online 1 July 2009

${ }^{*}$ Correspondence: Dr M Otter, Department of Child and Adolescent Psychiatry, Department of Adult Psychiatry, Printerweg 21/23, Amersfoort 3821 AP, The Netherlands.

Tel: +31 334571 717; Fax: +31 3186729 41; E-mail: maarten.otter@filternet.nl

Keywords: review; medical genetics; sex-chromosome aberrations; behavioural phenotypes of genetic syndromes; development; psychiatric disorders

Received 19 November 2008; revised 22 May 2009; accepted 26 May 2009; published online 1 July 2009 clinical descriptions of triple $\mathrm{X}$ syndrome before the technique of karyotyping became available. ${ }^{8-11}$

In cases of prenatal diagnosis, parents and clinical genetic counsellors needed information about this syndrome. The review by Nielsen has been worthwhile; ${ }^{12}$ this information is freely available on the internet and has been translated into several languages by parent support groups (see for instance: http://www.triple-x-syndroom.nl). After postnatal diagnosis, this information is useful for parents and for clinical geneticists, paediatricians, gynaecologists, (child) neurologists, (child) psychiatrists and others. This article aims to provide another up-to-date review of the literature.

After having described the literature search method, we will present literature findings on physical and psychological/behavioural issues. We will then discuss the findings taken from several age groups and offer some suggestions for future research.

\section{MATERIALS AND METHODS}

Reference bias is a major confounder in the literature on triple $\mathrm{X}$ syndrome. In studies with a high level of reference bias, one might get the impression that triple $\mathrm{X}$ syndrome is associated with a high level of malformations and pathology. ${ }^{13,14}$ This is in contrast with studies with low levels of reference bias.

The lowest level of bias in the field of SCA is found in newborn screening studies, initiated by the March of Dimes Birth Defects Foundation. We will refer to them in this paper as 'unbiased studies' or 'newborn-screening studies' in the description of development in the consecutive age groups. The March of Dimes Birth Defects Foundation organized a conference in Aspen in 1974. The visiting researchers decided to screen almost 200000 newborns from several cities (Aarhus, Denmark; Toronto, Canada; New Haven, Connecticut, USA; Denver, Colorado, USA; Edinburgh, Scotland and Winnipeg, Canada) for SCA. The cases with SCA were investigated in a prospective study design for 20 years 
Table 1 Growth and development in triple $X$ syndrome according to the results of unbiased studies

\begin{tabular}{|c|c|c|c|c|}
\hline & Children $<6$ years of age $e^{15,19}$ & School children ${ }^{16,20}$ & Teenage girls 17,21 & $\begin{array}{l}\text { Adolescents and (young) } \\
\text { adults }^{18,22,27,28,30-32}\end{array}$ \\
\hline Physical growth & $\begin{array}{l}\text { Average maternal age: } 33 \text { years. } \\
\text { Mean birth weight } 400-500 \mathrm{~g} \\
\text { lower. Appearance at birth: } \\
\text { normal. Head circumference: } \\
\text { below } 50 \text { th\%. Height: almost } \\
\text { all are above } 50 \text { th\%. }\end{array}$ & $\begin{array}{l}\text { Increased growth velocity between } \\
4 \text { and } 8 \text { years of age. Height is } \\
\text { often above } 75 \text { th\%. Leg length } \\
\text { significantly increased. Increase } \\
\text { in weight less than in height. } \\
\text { Bone age } 1 \text { SD below normal. }\end{array}$ & $\begin{array}{l}\text { No summarized data. } \\
\text { Differences between cases } \\
\text { and controls seem to decrease. }\end{array}$ & No summarized data. \\
\hline Motor development & $\begin{array}{l}\text { Milestones of motor development } \\
\text { may be delayed. }\end{array}$ & $\begin{array}{l}\text { Sensory-motor-visual integration } \\
\text { problems }\end{array}$ & $\begin{array}{l}\text { Gross and fine motor develop- } \\
\text { ment continues to be below } \\
\text { that of controls. }\end{array}$ & $\begin{array}{l}\text { Adult cases cope with coordina- } \\
\text { tion problems by seeking } \\
\text { appropriate jobs. }\end{array}$ \\
\hline $\begin{array}{l}\text { Intellectual } \\
\text { development. }\end{array}$ & & $\begin{array}{l}\text { Verbal IQ: } 69.6 \% \text { below } 90 . \\
\text { Performance IQ: } 41.2 \% \text { below } 90 .\end{array}$ & $\begin{array}{l}\text { Verbal IQ: } 86.63 \text { (19.01.points } \\
\text { lower than controls) } \\
\text { Performance IQ: } 95.19 \text { ( } 14.41 \\
\text { points lower than controls) }\end{array}$ & $\begin{array}{l}\text { IQ findings in adults are in the } \\
\text { same range as far as they have } \\
\text { been assessed. }\end{array}$ \\
\hline $\begin{array}{l}\text { Receptive and } \\
\text { expressive language } \\
\text { development }\end{array}$ & In half of the cases delayed. & $\begin{array}{l}\text { Some language difficulties in } \\
75 \% \text { of cases }\end{array}$ & $\begin{array}{l}\text { Poor language skills continue } \\
\text { to interfere with development. }\end{array}$ & $\begin{array}{l}\text { Language problems continue as } \\
\text { far as they have been assessed. }\end{array}$ \\
\hline $\begin{array}{l}\text { Social and beha- } \\
\text { vioural development. }\end{array}$ & $\begin{array}{l}\text { Some cases show temper } \\
\text { tantrums. }\end{array}$ & $\begin{array}{l}\text { Difficulties in forming good } \\
\text { interpersonal relationships. }\end{array}$ & $\begin{array}{l}\text { Behavioural problems noted as } \\
\text { often in cases as in controls. } \\
\text { Sensitivity to (un)stable family } \\
\text { functioning. }\end{array}$ & $\begin{array}{l}\text { Adult cases sometimes show } \\
\text { problems in establishing } \\
\text { satisfying relationships. } \\
\text { Low self-esteem. }\end{array}$ \\
\hline $\begin{array}{l}\text { Educational } \\
\text { development }\end{array}$ & & $\begin{array}{l}\text { Educational problems in } 74.1 \% \\
\text { in cases and } 44.4 \% \text { in controls. }\end{array}$ & $\begin{array}{l}\text { Educational problems in } 71.4 \% \\
\text { in cases and } 31.0 \% \text { in controls. }\end{array}$ & $\begin{array}{l}\text { After leaving school, cases seem } \\
\text { to feel better. }\end{array}$ \\
\hline
\end{tabular}

or, in the cases from Edinburgh and Denver, even longer. These researchers met four times from 1979 until 1989. The conference proceedings were published in four issues of the Birth Defect Original Article Series, ${ }^{15-18}$ and each editor published a summary of the results. ${ }^{19-22}$ These issues give detailed information on the development of triple X syndrome (and other SCA) collected by multidisciplinary teams consisting of clinical cytogeneticists, paediatricians, psychologists, psychiatrists, social workers and speech and language therapists. No (child) neurologists, endocrinologists or ophthalmologists were involved.

We carried out a PubMed search using the following search terms: 'superfemale, 'sex chromosomal disorder', 'sex chromosomal anomaly', 'sex chromosome aneuploidy', 'triple X (syndrome)', 'triplo X (syndrome)' and '47, XXX'. These studies are more or less biased because of referral bias. We scrutinized references for every paper, book, etc. This was necessary to find papers from the Oldmedline database, ${ }^{13,23,24}$ chapters of books ${ }^{25}$ and theses, ${ }^{26-28}$ etc. $^{29}$

When referring to reviews, we did not refer to any references mentioned therein to keep this paper as concise as possible. We excluded case reports on single cases, as it is not clear whether the level of incidence goes beyond pure coincidence. We focused on studies with clinical information and excluded others, e.g. papers focusing exclusively on molecular biology.

\section{Development and clinical features in triple $\mathrm{X}$ syndrome}

To describe development in triple $\mathrm{X}$ syndrome in relation to age, we arranged the available data in consecutive age groups, starting with the prenatal cases. In each postnatal age group, we described physical development based on the newborn screening, unbiased, studies and added data from biased studies; psychological and behavioural development are subsequently described in a similar way (Table 1).

\section{Prenatal diagnosis}

To the best of our knowledge, prenatal cases of triple X syndrome have not been suspected on just clinical grounds. The association between trisomy $\mathrm{X}$ in the offspring and maternal age is not as strong as in trisomy $21 .{ }^{29} \mathrm{In}$ the newborn-screening studies, the average maternal age was 33 and the paternal age was $29 .{ }^{19}$

In cases of SCA in general, counsellors have questioned the reliability of the available data on these disorders. ${ }^{33,34}$ Many data were collected from biased case series as we mentioned above. Data from unbiased studies on development until adulthood became available in $1990,{ }^{22}$ almost 15 year after the first reports on genetic counselling in SCA. ${ }^{35,36}$

\section{7,XXX neonates: are there congenital malformations?}

In the first papers on the newborn-screening studies, 43 girls with an extra $\mathrm{X}$ chromosome were described. ${ }^{19}$ The prevalence seemed to be $0.1 \%{ }^{2}$ The mean birth weight was $2979 \mathrm{~g}, 400-500 \mathrm{~g}$ less than that in the controls. The aneuploid status would not have been suspected at birth. Only clinodactyly and epicanthal folds were seen as minor anomalies in some of the cases. Two cases were reported with congenital heart disease, one being a patent ductus arteriosus. ${ }^{19,37}$

The biased studies more often show malformations. Ten years after the first description of triple X syndrome, one-third of 155 cases had a congenital physical defect. ${ }^{13}$ In his thesis on 39 women with an extra X chromosome, Olanders ${ }^{38}$ reported non-specific facial dysmorphism (mandibular prognathism as well as retrognathism) and various minor hand and feet anomalies, with clinodactyly or short fifth finger being a rather frequent finding. In 8 of 39 cases, parents were available for a detailed history. No one suspected the aneuploid status of the girls when they were born. ${ }^{39}$ Guichet ${ }^{14}$ reported 2 of 190 cases with clubfoot (pes equinovarus). Heart anomalies are rare in triple $\mathrm{X}$ syndrome; ${ }^{14,40}$ the numbers do not exceed the population prevalence numbers on heart anomalies, this being $0.8 \%{ }^{41}$ Cases with strabismus have been described. $^{39,42}$ Haverty ${ }^{43}$ described 16 patients, including 13 previously reported patients, with genitourinary malformations (Table 2).

\section{Youngest 47,XXX girls}

The newborn-screening studies on early development contained data on the development of 49 girls. Their height seemed to be normal before they reached the age of four. Later, they seem to be somewhat taller, with 17 out of 20 girls being taller than the 50th percentile. Their legs are longer than expected for their heights. The head circumferences were smaller, with 19 of 25 of them below the 50th percentile. ${ }^{19}$

Seven cases from Aarhus, Denmark showed a significantly higher interpupillary distance. ${ }^{55}$ Twelve cases from Toronto showed FSH levels as low as girls with gonadal dysgenesis (eg Turner's syndrome). ${ }^{56}$ Eleven girls from 
Table 2 The number of published cases with physical and psychiatric disorders

\begin{tabular}{|c|c|c|}
\hline Kind of disorder in triple $X$ cases & $\begin{array}{l}\text { Number of } \\
\text { published cases }\end{array}$ & Literature references \\
\hline \multirow[t]{5}{*}{ Urogenital malformations } & \multirow[t]{5}{*}{24 cases } & Pfeiffer, $1967^{24}$ \\
\hline & & Olanders, $1975^{38}$ \\
\hline & & Ratcliffe, 199944 \\
\hline & & Haverty, $2004^{43}$ \\
\hline & & Guichet, $1996^{14}$ \\
\hline \multirow{5}{*}{$\begin{array}{l}\text { Premature ovarian failure or primary } \\
\text { amenorrhoea }\end{array}$} & \multirow[t]{5}{*}{21 cases } & Smith, $1974^{45}$ \\
\hline & & Castillo, $1992^{46}$ \\
\hline & & Guichet, $1996^{14}$ \\
\hline & & Holland, $2000^{47}$ \\
\hline & & Goswami, $2003^{48}$ \\
\hline \multirow[t]{4}{*}{ Epilepsy and EEG anomalies } & \multirow[t]{4}{*}{71 cases } & Olanders, $1975^{49}$ \\
\hline & & Ratcliffe, $1979^{37}$ \\
\hline & & Grosso, $2004^{50}$ ) \\
\hline & & Roubertie, $2006^{51}$ \\
\hline \multirow[t]{3}{*}{ Psychiatric disorders } & \multirow[t]{3}{*}{73 cases } & Olanders, $1975^{52}$ \\
\hline & & Woodhouse, $1992^{53}$ \\
\hline & & $\begin{array}{l}\text { Kanaka-Gantenbein, } \\
2004^{54}\end{array}$ \\
\hline
\end{tabular}

Denver started to walk later than the controls (11-22 months) and showed coordination problems. ${ }^{57}$

The full-scale IQ's were significantly lower than in controls. ${ }^{19}$ Language development (receptive and expressive language) was delayed in 19 out of 41 girls. Methodological problems made it difficult to make comparisons between the data from the participating research groups. More cases than controls showed shyness, un-cooperativeness, clumsiness and attention deficits. ${ }^{55}$ Two of the twelve girls from Toronto were referred for child psychiatric examination because of temper tantrums and resistive behaviour. ${ }^{56}$ Four of the eleven cases from Denver required psychiatric intervention because of externalizing or internalizing psychiatric disorders. There were signs of parental marital distress in 6 of 11 cases, higher than in other SCA syndromes. ${ }^{57}$ Three of the eleven cases from Edinburgh showed behavioural problems, one due to hyperactivity, one probably attributed to epilepsy and the other to shyness. ${ }^{37}$

\section{7,XXX girls at school}

Data on physical development from 6-13 years of age show 16 of 38 (42.1\%) 47,XXX girls grew $>90$ th percentile and 9 of $38(23.7 \%)$ grew $<50$ th percentile At ages between $4-8$ years, growth seemed to be faster. The leg length especially seemed to increase. Head circumference was significantly reduced from time of birth. Bone age was about 1 SD behind until the age of 7-10 years. Patients tended to be underweight for their height. ${ }^{20}$ Data on endocrinological examinations from the Toronto group showed a trend to be normal in FSH and LH levels and an augmented LH-RH response. ${ }^{8}$ Two other girls showed early puberty. ${ }^{59}$

With regard to psychological development, $69.9 \%$ of the girls showed a verbal IQ below 90 ( $12.5 \%$ in controls) and $41.2 \%$ showed a performance IQ lower than 90 (8.3\% in controls). Out of these 27 girls, $74.1 \%$ had some academic problems. ${ }^{20}$ The Edinburgh cases showed an IQ level at age seven being significantly correlated with head circumference at birth. ${ }^{60}$ During the conference, some remarks were made on difficulties in forming good interpersonal relationships. ${ }^{20}$ This could not be attributed to an atypical personality or one single kind of psychopathology. Three research groups showed a low score on the 'comprehension' subtest in the WISC..$^{58,61,62}$ Nielsen $^{61}$ showed that behavioural characteristics in the group with SCA were significantly different when compared with controls. This was true for 'fears' $(P=0.059)$, 'fits of rage'
( $P=0.038)$, 'feelings of inferiority' $(P=0.040)$, 'lack of self-confidence' $(P=0.003)$, 'sensitiveness' $(P=0.038)$ and 'easiness to get hurt' $(P=0.00001)$. The Toronto group emphasized (neuro)psychological deficits. The girls showed short-term memory and recall problems. Their behaviour was more masculine and more impulsive in several cases. They showed a decreased left hemisphere verbal ability, especially in the cases with lowest Total Finger Ridge Counts (TFRC). ${ }^{58,63}$ The New Haven research group held psychiatric interviews with their three cases: one showed no problems, one showed lack of self-confidence and the third showed a short attention span and irritability before she started a special programme at school. ${ }^{59}$ The Denver group reported auditory-processing deficits, which occurred in more than half of the cases. ${ }^{64}$ It seemed that the physical phenotype (being the tallest but immature and somewhat clumsy girl in the peer group, sometimes with precocious puberty) and the behavioural phenotype (speech and language disorders, sensory-integration disorders and academic difficulties) could explain some social problems. ${ }^{65}$

In eight cases, recruited by Olanders ${ }^{39}$ from schools for special education, the parents stated that these girls were shy and lacked self-confidence. They lagged in language development. They performed better in remedial classes in a school for special education, especially with the passage of time and gradually the girls got accustomed to the school environment, their schoolmates and teachers.

\section{The teenage 47,XXX girls}

Physical growth data show an earlier growth spurt and a somewhat lower weight than height percentile, significantly smaller head circumferences, shorter hands and feet, and with longer tibiae and underarms than in the controls. Puberty is sometimes delayed and at times occurs earlier than in general. ${ }^{66-68}$

Data on intelligence in 35 cases and 29 controls showed lower full-scale IQ's (cases $=90.06 v s$ controls $=108.40$ ), verbal IQ's (cases $=86.63 v s$ controls $=105.64$ ) and performance IQ's (cases $=95.16 v s$ controls $=109.60$ ), with significantly lower verbal IQ's than performance IQ's. Twenty-five cases and 11 controls were judged to have educational problems. Behavioural problems were judged to be less frequent in cases compared with controls. It seems that if educational and other kinds of support are provided during infancy, this will result in proper educational levels and support during adolescence. Twenty-five cases were judged to live in stable families; 18 in controls. The controls in some studies were the siblings of the cases and lived in the same family. The cases from poorly functioning homes had lower overall IQs than those from more stable environments. Ten cases lived in an unstable environment and always showed educational problems. In stable environments, 15 of 25 cases showed educational problems; 22 of 35 cases, growing up in stable families, showed no behavioural problems. $^{21}$

\section{The adolescent and young adult $47, \mathrm{XXX}$ women}

Forty-six girls between the ages of 11 and 24 were continued to be followed-up, 37 girls being 15 years or older. These girls were in good health. Twenty-five percent suffered from 'non-organic' abdominal pains. Their final height was commonly at or above the 90th percentile except when their parents were short in height. The mean weights were between the 60-70th percentiles, so they were relatively underweight for their height. Poor coordination, 'clumsiness', had remained with them from childhood on. Just a few girls actively took part in sports. ${ }^{22}$ The young women showed normal female sexual development and 9 out of 37 delivered a chromosomally normal child. No details were reported on the follow-up of these 47,XXX mothers and their children. ${ }^{22}$

Intelligence tended to cluster in the lower levels of normal intelligence, being significantly lower than their siblings. The verbal IQ levels continued to be lower than the performance IQ levels and expressive language continued to be poor. The majority (22 of 37) attended special education classes in high school, 7 of 37 dropped out of high school and 3 of 37 attended college. The psychosocial adaptation seemed to be reasonably good, with 25 of 37 showing no behavioural problems. ${ }^{22}$ Several research groups-again ${ }^{20}$-reported poor interpersonal relationships and sensitivity to a stressful home life. The 47,XXX women depended longer on parental support than did their siblings. ${ }^{22}$ They planned to take jobs requiring low academic and linguistic skills. ${ }^{69,70}$

Olanders ${ }^{39}$ reported five adolescent cases. These girls found unskilled labour after leaving school. They were still dependent on parental support. 


\section{The adult 47,XXX women}

After the fourth international meeting on the newborn-screening studies, the research groups from Edinburgh and Denver continued the follow-up. In Edinburgh, Götz and Warwick described neuro-imaging, psychological and psychiatric findings in an unbiased group up to 32 years of age. They reported no data on physical growth and development. In Denver, Robinson and his co-workers, continued to report on the girls and women until 2002. ${ }^{71-75}$

Both research groups carried out MRI studies of the brain in the newbornscreening group. Lower total brain volumes and larger and asymmetric ventricles were reported as developmental effects of the extra X chromosome on brain development. ${ }^{28,76,77}$ Warwick et $a 2^{28}$ were not able to show any association between any regions of interest and schizotypal traits. The Denver group found a possible correlation between every extra X chromosome and small reductions in amygdala volumes. In contrast to the Klinefelter cases, this result was not significant after co-varying for overall reductions in whole-brain volume. ${ }^{77}$

Olanders described an increased prevalence of thoracic kyphosis in 15 of 33 cases, a short neck in 10 of 33 cases and scoliosis in 5 of 33 cases. Ten of his 25 adult cases ( $>25$ years of age) proved to be fertile. ${ }^{39}$ After the first papers on fertile $47, \mathrm{XXX}$ women, ${ }^{78,79}$ fertility no longer seemed to be an issue.

As far as we know, there is just one report on a $47, \mathrm{XXX}$ woman with a 47,XXX offspring. ${ }^{43}$ Premature ovarian failure probably does exceed the population risk ${ }^{45,46,80,48}$ (Table 2).

The newborn-screening studies did not involve EEG recordings. One case of epilepsy was reported. This girl was reported to be extremely shy and had frequent temper tantrums. The details about the therapy have not been published. ${ }^{37}$ Olanders ${ }^{49}$ reported in his case series some form of paroxysmal abnormality in $13 / 21$ cases, in four cases after photic stimulation. A common finding was a low-frequency background. His literature review showed that paroxysmal activity or increased photosensitivity occurred in 13/48 cases. These results were comparable with those found in Klinefelter syndrome. ${ }^{81}$ Other authors suggested that EEG anomalies in triple $\mathrm{X}$ syndrome are associated with mental retardation. Treatment with carbamazepine was effective in all but one case $^{50,51}$ (Table 2).

IQ scores in the Edinburgh group showed data similar to earlier findings in the same cases. Common findings in psychiatric interviews consisted of slow psychic tempo, fatigability, under-initiative in making social contact, limited ability in verbal and non-verbal language and conversation skills, an anxious affective display, an asthenic appearance and low self-esteem, with low self-esteem being the most common finding. Four of the sixteen triple $\mathrm{X}$ girls (in controls 2 of 75) were referred to a psychiatrist: one case of trichotillomania and three cases of behavioural disorders. Two of these four patients were diagnosed with a major depressive disorder. Two cases were diagnosed as cyclothymic personality and three for labile personality. One case suffered from non-psychotic ideas of reference and dissociative periods. ${ }^{82}$

Warwick ${ }^{83}$ re-examined these cases three years later and found increased social anxiety, suspiciousness, restricted emotion and impulsivity/non-conformity. Antisocial and schizotypical traits were rare but more prevalent in cases than in controls. The same was true for irritability and anger. These were associated with lower scores on IQ testing. There seemed to be some improvement in quality of life after leaving school.

The Denver group described the occurrence of learning disabilities, language disorders and motor disorders in young adults: 'The (unselected) 47,XXX women during adolescence and young adulthood were less well adapted; had more stress; had more work, leisure and relationship problems; had a lower IQ; and showed more psychopathology when contrasted with the comparison group. ${ }^{84}$ Eight of the eleven 47,XXX females showed neurocognitive and psychosocial impairment. . $^{7,85,30,31}$ They carried out follow-up examinations on these girls and other cases, which had been diagnosed prenatally. Apparently, the prenatally diagnosed were of a higher socio-economic status, predicting a higher level of functioning. ${ }^{32}$

Psychotic disorders have been described in 47,XXX syndrome (Table 2). ${ }^{52,53,86}$ Olanders ${ }^{39}$ described 20 adult cases recruited from mental hospitals; in these cases, the psychiatric illness started between 22 and 73 years of age. Four of these women required an inpatient treatment, as they were under the age of 32. In general, psychotic symptoms reacted well to standard neuroleptic treatment. Olanders ${ }^{39}$ reported effective treatment in four cases using electro-convulsive therapy. No findings were reported on the treatment of psychiatric symptoms using anti-epileptic drugs. ${ }^{49}$

To the best of our knowledge, no data are available on old age development in triple X syndrome.

\section{DISCUSSION}

Although there seems to be a general consensus on providing genetic information in a nondirective manner, ${ }^{87}$ parents have received conflicting information after a prenatal SCA diagnosis. ${ }^{88,89}$ After a prenatal triple X diagnosis, a lower pregnancy termination rate is reported than in Klinefelter syndrome. ${ }^{90,91}$ Severe abnormalities in ultrasound examinations before or after prenatal diagnosis increase termination rates. ${ }^{92}$ There are major cultural differences in prenatal counselling. ${ }^{93,94}$ For instance, in Israel, high rates of termination are reported, ${ }^{95}$ but low rates are reported in Germany. ${ }^{96,97}$ The reports on development in unbiased groups with SCA seem to be responsible for a trend of a decline in termination rates. ${ }^{98-101}$

In neonatal cases with malformations, there are no reports on prevalence numbers that exceed the population risk. The only exception may be genitourinary malformations (Table 2). In cases with a prenatal 47,XXX diagnosis, it seems to be common sense to give special attention to the urogenital tract in prenatal ultrasound investigations to offer the opportunity of early intervention after birth.

The youngest cases seem to suffer from a delay in language development. Auditory-processing disorders may be responsible for this delay. Furthermore, delay in language development may be responsible for a delay in social cognition and functioning. ${ }^{102}$ This might explain some of the problems in forming stable interpersonal relationships.

Clear endocrine disorders have been found in adolescent Klinefelter boys and testosterone therapy has been accepted. ${ }^{103}$ In triple X syndrome, endocrinological findings from the newborn-screening study are not available. This may have consequences for the psychological development. Estrogen functions as a neuroprotective agent so, if women lack sufficient estrogen levels, this might (partially) explain behavioural disorders. ${ }^{104-107}$

Several studies have described psychiatric disorders in adults. It may be difficult to make a comparison with modern studies because these studies did not use the currently accepted classification according to the DSM IV-TR. ${ }^{108}$ Moreover, it is necessary to consider that cases from the newborn-screening studies have not yet been examined in their thirties, an age at which vulnerability for psychiatric disorders is expected to become clinically recognizable.

Most of the published triple $\mathrm{X}$ patients with psychotic disorders show paranoid symptoms. ${ }^{52}$ Low self-esteem has been reported in almost all the young adult women in the Edinburgh newborn-screening study. ${ }^{82}$ Psychological studies have shown an association between low and unstable self-esteem in paranoid patients. ${ }^{109,110}$ Further research is necessary to know whether this may (partially) explain the prevalence of paranoid symptoms in psychotic triple $\mathrm{X}$ women. Some authors argue that psychosis in cytogenetic disorders might shed some light on the aetiology of psychosis and we agree. ${ }^{11,112}$

Although developmental biology is not the focus of this review, further research in this field may yield a better understanding and findings may be clinically relevant. We want to highlight three issues: the concept regarding the slowing down of cell cycles in trisomic cells as an explanation of the phenotype in developmental disorders, the influence of the slowing down of the cell cycles on foetal and adult neurogenesis and the question of whether incomplete $\mathrm{X}$-chromosomal inactivation in trisomy $\mathrm{X}$ might negatively influence brain development.

So first, Polani (1977) and others have discussed decreased cell-division rates in SCA syndromes as a probable explanation of the phenotype as reflected in dermatoglyphics ${ }^{113}$ and reduced brain volumes ${ }^{114,115}$ in SCA.25,116 The cell cycle slows down in cases with an extra $\mathrm{X}$ chromosome ${ }^{117}$ and in other cells with an extra chromosome in humans ${ }^{117,118}$ as well as in yeast ${ }^{119}$ and in seedlings. ${ }^{120}$ DNA replication is apparently the rate-limiting step in the cell cycle. ${ }^{120}$

Secondly, there is a growing body of literature on the association between psychiatric diseases and adult neurogenesis. ${ }^{121-124}$ The dysfunction of DISC1 (disrupted-in-schizophrenia-1) disrupts adult neurogenesis and causes a variety of psychotic and affective disorders. ${ }^{125}$ Adult neurogenesis is relevant to the 
Table 3 Preventive management

\begin{tabular}{|c|c|c|}
\hline & Physical management & Psychological management \\
\hline Prenatal period & $\begin{array}{l}\text { Ultrasound examination with special attention on } \\
\text { the urogenital region. }\end{array}$ & - \\
\hline Neonatal period & Paediatric examination. & - \\
\hline \multirow[t]{2}{*}{ Kindergarten period } & $\begin{array}{l}\text { 1) EEG examination. } \\
\text { 2) Neurological examination of the child, focusing } \\
\text { on coordination disorders. }\end{array}$ & $\begin{array}{l}\text { 1) Neuropsychological investigation and subsequent educational support if necessary } \\
\text { 2) Linguistic investigation. }\end{array}$ \\
\hline & 3) Ophthalmological examination. & 3) Support of parents, the family, teachers and the $47, X X X$ girl. \\
\hline Primary-school period & $\begin{array}{l}\text { 1) EEG examination, if earlier examination failed. } \\
\text { 2) Ophthalmological examination. }\end{array}$ & $\begin{array}{l}\text { 1) Auditory function investigation. } \\
\text { 2) Psychological investigation with focus on social functioning. } \\
\text { 3) Neuropsychological investigation and subsequent definition of educational needs. } \\
\text { 4) Support of parents, the family, teachers and the } 47, X X X \text { girl. }\end{array}$ \\
\hline Teenage girls & & $\begin{array}{l}\text { 1) Psychological investigation focusing on social functioning. } \\
\text { 2) Neuropsychological investigation and subsequent definition of educational needs. } \\
\text { 3) Support of parents, the family, teachers and the } 47, X X X \text { girl. }\end{array}$ \\
\hline $\begin{array}{l}\text { Adolescents and young } \\
\text { adults }\end{array}$ & $\begin{array}{l}\text { Physical examination in case of clinical signs and } \\
\text { symptoms. }\end{array}$ & Occupational investigation and subsequent occupational support, if necessary. \\
\hline Adults & $\begin{array}{l}\text { Physical examination in case of clinical signs and } \\
\text { symptoms. }\end{array}$ & Psychological/psychiatric examination in case of clinical signs and symptoms. \\
\hline
\end{tabular}

function of the amygdala, hippocampus, the olfactory region and the substantia nigra. ${ }^{126,127}$ A slowing of the cell-division rate might-as in prenatal development of the brain-influence the efficacy of adult neurogenesis. Further research in triple $\mathrm{X}$ syndrome might throw more light on the aetiology of psychotic and affective disorders through delayed adult neurogenesis.

Thirdly, without the inactivation of the second X chromosome, women would not survive (for a review see Migeon ${ }^{128}$ ). A recent study has shown that this inactivation is incomplete. Fifteen percent of the $\mathrm{X}$ chromosomal genes are just partially inactivated or not inactivated. ${ }^{129-131}$ In men with an extra X chromosome, the second X chromosome is inactivated. However, RNA studies in Klinefelter have proven that there are differences in RNA levels between XY and XXY men. ${ }^{132}$ The third X chromosome in $47, \mathrm{XXX}$ women seems to be inactivated. ${ }^{133}$ However, it seems to be reasonable to hypothesize that in XXX females, RNA levels differ from XX controls. The X chromosomal genetic disorders are often related to mental retardation. Many X chromosomal genes must be involved in brain development. ${ }^{134}$ So an unbalanced expression of $\mathrm{X}$ chromosomal genes may contribute to sub-optimal brain development. The neuropathological studies will be necessary to throw more light on typical and atypical brain development in trisomy syndromes.

Until now, these three scientific issues have almost not been studied in humans or in animal models, although animal models are available, especially in infertile cattle. ${ }^{135-138}$

\section{Preventive management}

Preventive management is meant to prevent developmental and educational delay. As we mentioned above, EEG abnormalities, urogenital disorders and ophthalmological disorders seem to be more common in triple $\mathrm{X}$ syndrome and require clinical attention (Table 2). We recommend regular neuropsychological and linguistic testing using test batteries suited to the consecutive age groups. Our threshold for a thorough assessment is even lower than that recommended by others. ${ }^{139}$ It is our clinical experience that developmental, behavioural or educational difficulties are often caused by linguistic, auditory and neurocognitive disorders as well as a lack of awareness and understanding on the part of clinicians, parents, teachers, etc. (Table 3).

\section{CONCLUSION}

Triple $\mathrm{X}$ syndrome is a syndrome with a high level of variety in the physical and behavioural phenotype. Triple $\mathrm{X}$ syndrome is not rare, but it is often undiagnosed. Notwithstanding the relatively high prevalence of triple $\mathrm{X}$ syndrome, there are many issues yet to be studied in physical and behavioural development up to old age.

First of all, it would be interesting to continue the follow-up of the girls from the unbiased longitudinal studies and start new cohorts of longitudinal studies. In psychiatric research, it would be interesting to study the relation between low self-esteem and paranoid ideations. In addition, the relations between auditory-processing disorders, language development and the development of social cognition may yield insight into the development of difficulties in forming satisfying relationships and how to treat disorders in this area.

Triple X syndrome may serve as a model for studying the physical and behavioural aspects of developmental delay. The process of X chromosome inactivation in trisomy $\mathrm{X}$ and other scientific issues require further study. In this field, insight into the pathology may yield more insight into the physiology.

Above all, further study is needed to establish evidence-based treatment and support protocols in physical treatments (endocrinological treatment, fertility issues and treatment in cases with EEG anomalies in relation to behaviour, etc.), educational support, psychiatric diagnosis and treatment, and psychological treatment, such as psychotherapy and family therapy.

1 Gustavson $\mathrm{KH}$ : Triple $\mathrm{X}$ syndrome deviation with mild symptoms. The majority goes undiagnosed. Lakartidningen 1999; 96: 5646-5647.

2 Jacobs PA: The incidence and etiology of sex chromosome abnormalities in man. Birth Defects Orig Artic Ser 1979; 15: 3-14.

3 Robinson A, Linden MG, Bender BG: Prenatal diagnosis of sex chromosomal abnormalities. In: Milunsky A (ed): Genetic Disorders and the Fetus; Diagnosis, Prevention and Treatment, 4th edn Baltimore and London: Johns Hopkins, 1998, pp 249-285.

4 Lejeune J, Gautier M, Turpin R: Study of somatic chromosomes from 9 mongoloid children. C R Hebd Seances Acad Sci 1959; 248: 1721-1722.

5 Jacobs PA, Strong JA: A case of human intersexuality having a possible XXY sex-determining mechanism. Nature 1959; 183: 302-303.

6 Ford CE, Jones KW, Polani PE, De Almeida JC, Briggs JH: A sex-chromosome anomaly in a case of gonadal dysgenesis (Turner's syndrome). Lancet 1959; 273: 711-713.

7 Jacobs PA, Baikie AG, Court Brown WM, MacGregor TN, Maclean N, Harnden DG: Evidence for the existence of the human 'super female'. Lancet 1959; 274: $423-425$.

8 Levitas AS, Reid CS: An angel with Down syndrome in a sixteenth century Flemish Nativity painting. Am J Med Genet A 2003; 116: 399-405. 
9 Brain L: Historical introduction. In: Wolstenholme GEW, Porter R (eds): Mongolism: In Commemoration of Dr John Langdon Haydon Down. Boston: Little, Brown and Company, 1967, pp 1-5.

10 Klinefelter HF, Reifenstein EC, Albright F: Syndrome characterised by gynaecomastia, aspermatogenesis, without, A-leydigism and increased excretion of follicle-stimulating hormone. J Clin Endocrinol 1942; 2: 615-627.

11 Turner $\mathrm{HH}$ : A syndrome of infantilism, congenital webbed neck and cubitus valgus. Endocrinology 1938; 23: 566-574.

12 Nielsen J: Triple-X females. An orientation, 1989, available at http://www.turnercenteret. dk/engelsk/triplex.htm.

13 Barr ML, Sergovich FR, Carr DH, Saver EL: The triplo-X female: an appraisal based on a study of 12 cases and a review of the literature. Can Med Assoc J 1969; 101: 247-258.

14 Guichet A, Briault S, Moraine C, Turleau C: Trisomy X: ACLF (Association des Cytogeneticiens de Langue Francaise) retrospective study. Ann Genet 1996; 39: 117-122.

15 Robinson A, Lubs HA, Bergsma D: Sex chromosome aneuploidy: prospective studies on children. Birth Defects Orig Artic Ser 1979; 15: 1-281.

16 Stewart DA: Children with sex chromosome aneuploidy: follow-up studies. Birth Defects Orig Artic Ser 1982; 18: 1-251.

17 Ratcliffe SG, Paul N: Prospective studies on children with sex chromosome aneuploidy. Birth Defects Orig Artic Ser 1986; 22: 1-328.

18 Evans JA, Hamerton JL, Robinson A: Children and young adults with sex chromosome aneuploidy. Birth Defects Orig Artic Ser 1990; 26: 1-312.

19 Robinson A, Lubs HA, Nielsen J, Sorensen K: Summary of clinical findings: profiles of children with 47,XXY, 47, XXX and 47, XYY karyotypes. Birth Defects Orig Artic Ser 1979; 15: 261-266.

20 Stewart DA, Netley CT, Park E: Summary of clinical findings of children with 47,XXY, 47,XYY, and 47,XXX karyotypes. Birth Defects Orig Artic Ser 1982; 18: 1-5.

21 Netley CT: Summary overview of behavioural development in individuals with neonatally identified $X$ and $Y$ aneuploidy. Birth Defects Orig Artic Ser 1986; 22: 293-306.

22 Robinson A, Bender BG, Linden MG: Summary of clinical findings in children and young adults with sex chromosome anomalies. Birth Defects Orig Artic Ser 1990; 26: 225-228.

23 Gilgenkrantz S, Gilgenkrantz JM, Streiff F, Fauchier JP, Baillon D: Syndrome triplo X et anomalies squelettiques. Ann Med Nancy 1967; 6: 172-186.

24 Pfeiffer RA, Palm D, Jochmus J: [The clinical aspects of trisomy of the X-chromosomes in adolescents (triple X-syndrome)]. Monatsschr Kinderheilkd 1967; 115: 9-18.

25 Polani PE: Abnormal sex chromosomes, behaviour and mental disorder; in Tanner JM (ed): Developments in Psychiatric Research. London: Mental Health Foundation, 1977, pp 89-128.

26 Olanders S: Females with Supernumerary X Chromosomes; A Study of 39 Psychiatric Cases. Göteborg: University of Göteborg, 1975.

27 Gotz M: The Psychiatric Consequences of Sex Chromosome Abnormalities: A Cohort Study. Edinburgh: University of Edinburgh, 1996

28 Warwick MM: Brain Morphology and Personality Characteristics of Subjects with Sex Chromosome Anomalies and Matched Controls. Edinburgh: University of Edinburgh, 1999.

29 Penrose LS: Review of WM Court Brown, editor, Abnormalities of the sex chromosome complement in man. Ann Hum Genet 1964; 28: 199-200.

30 Bender BG, Linden MG, Harmon RJ: Neuropsychological and functional cognitive skills of 35 unselected adults with sex chromosome abnormalities. Am J Med Genet 2001; 102: 309-313.

31 Bender BG, Linden MG, Harmon RJ: Life adaptation in 35 adults with sex chromosome abnormalities. Genet Med 2001; 3: 187-191.

32 Linden MG, Bender BG: Fifty-one prenatally diagnosed children and adolescents with sex chromosome abnormalities. Am J Med Genet 2002; 110: 11-18.

33 Robinson A: Introduction. Birth Defects Orig Artic Ser 1979; 15: 1-2.

34 Leschot NJ, Verjaal M, Treffers PE: A critical analysis of 75 therapeutic abortions. Early Hum Dev 1985; 10: 287-293.

35 Krone LR, Prichard LL, Bradshaw CL, Jones OW, Peterson RM, Dixson BK: Antenatal diagnosis of an XXX female. A dilemma for genetic counseling. West J Med 1975; 123: 17-21.

36 Mueller-Heubach E, Garver KL, Ciocco AM: Prenatal diagnosis of trisomy X: its implications for genetic counseling. Am J Obstet Gynecol 1977; 127: 211-212.

37 Ratcliffe SG, Axworthy D, Ginsborg A: The Edinburgh study of growth and development in children with sex chromosome abnormalities. Birth Defects Orig Artic Ser 1979; 15: 243-260.

38 Olanders S: Somatic findings. In: Olanders $S($ ed): Females with Supernumerary $X$ Chromosomes; A Study of 39 Psychiatric Cases. Göteborg: University of Göteborg, 1975, pp 41-60.

39 Olanders S: Case histories. In: Olanders S (ed): Females with Supernumerary $X$ Chromosomes; A Study of 39 Psychiatric Cases. Göteborg: University of Göteborg, 1975, pp 108-204.

40 Emerit I, de Grouchy J, Vernant P, Corone P: Chromosomal abnormalities and congenital heart disease. Circulation 1967; 36: 886-905.

41 Fixler DE: Epidemiology of Congenital Heart Disease; in McMillan JA, Feigin RD, DeAngelis C, Jones MD (eds): Oski's Principles \& Practice of Pediatrics. Philadelphia: Lippincott Williams \& Wilkins, 2006, pp 335-338.

42 Francois J, Berger JFR, Saraux H: Anomalies des chromosomes sexuels; Trisomie X; in: Francois J, Berger JFR, Saraux H (eds): Les Aberrations Chromosomiques En Ophtalmologie. Paris: Masson \& Cie, 1972, pp 389-394.
43 Haverty CE, Lin AE, Simpson E, Spence MA, Martin RA: 47,XXX associated with malformations. Am J Med Genet A 2004; 125: 108-111.

44 Ratcliffe S: Long-term outcome in children of sex chromosome abnormalities. Arch Dis Child 1999; 80: 192-195.

45 Smith HC, Seale JP, Posen S: Premature ovarian failure in a triple X female. J Obstet Gynaecol Br Commonw 1974; 81: 405-409.

46 Castillo S, Lopez F, Tobella L, Salazar S, Daher V: The cytogenetics of premature ovarian failure. Rev Chil Obstet Ginecol 1992; 57: 341-345.

47 Holland C: 47,XXX in an adolescent with premature ovarian failure and autoimmune disease. J Pediatr Adolesc Gynecol 2000; 13: 93.

48 Goswami R, Goswami D, Kabra M, Gupta N, Dubey S, Dadhwal V: Prevalence of the triple $\mathrm{X}$ syndrome in phenotypically normal women with premature ovarian failure and its association with autoimmune thyroid disorders. Fertil Steril 2003; 80: 1052-1054.

49 Olanders S, Selldén U: Electroencephalografic investigation; in Olanders S (ed): Females with Supernumerary X Chromosomes; A Study of 39 Psychiatric Cases. Göteborg, Sweden: University of Göteborg, 1975, pp 77-85.

50 Grosso S, Farnetani MA, Di Bartolo RM et al: Electroencephalographic and epileptic patterns in X chromosome anomalies. J Clin Neurophysiol 2004; 21: 249-253.

51 Roubertie A, Humbertclaude V, Leydet J, Lefort G, Echenne B: Partial epilepsy and 47,XXX karyotype: report of four cases. Pediatr Neurol 2006; 35: 69-74.

52 Olanders S: Other psychiatric findings; in Olanders S (ed): Females with Supernumerary X Chromosomes; A Study of 39 Psychiatric Cases. Göteborg, University of Göteborg, 1975, pp 91-104.

53 Woodhouse WJ, Holland AJ, McLean G, Reveley AM: The association between triple X and psychosis. Br J Psychiatry 1992; 160: 554-557.

54 Kanaka-Gantenbein C, Kitsiou S, Mavrou A et al: Tall stature, insulin resistance, and disturbed behavior in a girl with the triple $X$ syndrome harboring three SHOX genes: offspring of a father with mosaic Klinefelter syndrome but with two maternal $X$ chromosomes. Horm Res 2004; 61: 205-210.

55 Nielsen J, Sillesen I, Sorensen AM, Sorensen K: Follow-up until age 4-8 of 25 unselected children with sex chromosome abnormalities, compared with sibs and controls. Birth Defects Orig Artic Ser 1979; 15: 15-73.

56 Stewart DA, Netley CT, Bailey JD et al: Growth and development of children with X and Y chromosome aneuploidy: a prospective study. Birth Defects Orig Artic Ser 1979; 15: 75-114.

57 Robinson A, Puck M, Pennington B, Borelli J, Hudson M: Abnormalities of the sex chromosomes: a prospective study on randomly identified newborns. Birth Defects Orig Artic Ser 1979; 15: 203-241.

58 Stewart DA, Bailey JD, Netley CT et al: Growth and development of children with X and $Y$ chromosome aneuploidy from infancy to pubertal age: the Toronto study. Birth Defects Orig Artic Ser 1982; 18: 99-154.

59 Leonard MF, Sparrow S, Schowalter JE: A prospective study of development of children with sex chromosome anomalies - New Haven study III. The middle years. Birth Defects Orig Artic Ser 1982; 18: 193-218.

60 Ratcliffe SG, Masera N, Pan H, McKie M: Head circumference and IQ of children with sex chromosome abnormalities. Dev Med Child Neurol 1994; 36: 533-544.

61 Nielsen J, Sorensen AM, Sorensen K: Follow-up until age 7-11 of 25 unselected children with sex chromosome abnormalities. Birth Defects Orig Artic Ser 1982; 18: 61-97.

62 Ratcliffe SG, Tierney I, Nshaho J, Smith L, Springbett A, Callan S: The Edinburgh study of growth and development of children with sex chromosome abnormalities. Birth Defects Orig Artic Ser 1982; 18: 41-60.

63 Hreczko TA, Sigmon BA: The dermatoglyphics of a Toronto sample of children with XXY, XXYY, and XXX aneuploidies. Am J Phys Anthropol 1980; 52: 33-41.

64 Bender B, Fry E, Pennington B, Puck M, Salbenblatt J, Robinson A: Speech and language development in 41 children with sex chromosome anomalies. Pediatrics 1983; 71: 262-267.

65 Robinson A, Bender B, Borelli J, Puck M, Salbenblatt J, Webber ML: Sex chromosomal abnormalities (SCA): a prospective and longitudinal study of newborns identified in an unbiased manner. Birth Defects Orig Artic Ser 1982; 18: 7-39.

66 Evans JA, de von Flindt R, Greenberg C, Ramsay S, Hamerton JL: A cytogenetic survey of 14069 newborn infants. IV. Further follow-up on the children with sex chromosome anomalies. Birth Defects Orig Artic Ser 1982; 18: 169-184.

67 Stewart DA, Bailey JD, Netley CT, Rovet J, Park E: Growth and development from early to midadolescence of children with $X$ and $Y$ chromosome aneuploidy: the Toronto Study. Birth Defects Orig Artic Ser 1986; 22: 119-182.

68 Ratcliffe SG, Murray L, Teague P: Edinburgh study of growth and development of children with sex chromosome abnormalities. III. Birth Defects Orig Artic Ser 1986; 22: 73-118.

69 Linden MG, Bender BG, Harmon RJ, Mrazek DA, Robinson A: 47,XXX: what is the prognosis? Pediatrics 1988; 82: 619-630.

70 Robinson A, Bender BG, Linden MG, Salbenblatt JA: Sex chromosome aneuploidy: the Denver Prospective Study. Birth Defects Orig Artic Ser 1990; 26: 59-115.

71 Bender BG, Linden M, Robinson A: Cognitive and academic skills in children with sex chromosome abnormalities. Read Writ 1991; 3: 315-327.

72 Bender BG, Linden MG, Robinson A: Neuropsychological impairment in 42 adolescents with sex chromosome abnormalities. Am J Med Genet 1993; 48: 169-173.

73 Bender BG, Harmon RJ, Linden MG, Robinson A: Psychosocial adaptation of 39 adolescents with sex chromosome abnormalities. Pediatrics 1995; 96: 302-308.

74 Bender BG, Harmon RJ, Linden MG, Bucher-Bartelson B, Robinson A: Psychosocial competence of unselected young dults with sex chromosome abnormalities. Am J Med Genet 1999; 88: 200-206. 
75 Linden MG, Bender BG, Robinson A: Genetic counseling for sex chromosome abnormalities. Am J Med Genet 2002; 110: 3-10.

76 Warwick MM, Doody GA, Lawrie SM, Kestelman JN, Best JJ, Johnstone EC: Volumetric magnetic resonance imaging study of the brain in subjects with sex chromosome aneuploidies. J Neurol Neurosurg Psychiatry 1999; 66: 628-632.

77 Patwardhan AJ, Brown WE, Bender BG, Linden MG, Eliez S, Reiss AL: Reduced size of the amygdala in individuals with 47, XXY and 47,XXX karyotypes. Am J Med Genet 2002; 114: 93-98.

78 Stewart JS, Sanderson AR: Fertility and oligophrenia in an apparent triplo-X female. Lancet 1960; 276: 21-23.

79 Fraser JH, Campbell J, MacGillivray RC, Boyd E, Lennox B: The XXX syndrome frequency among mental defectives and fertility. Lancet 1960; 276: 626-627.

80 Holland CM: 47,XXX in an adolescent with premature ovarian failure and autoimmune disease. J Pediatr Adolesc Gynecol 2001; 14: 77-80.

81 Hambert G: Males with Positive Sex Chromatin; An Epidemiologic Investigation Followed by Psychiatric Study of Seventy-Five Cases. Göteborg, University of Göteborg, 1966.

82 Gotz M: Results of the present study: XXX women; in Gotz M (ed): The Psychiatric Consequences of Sex Chromosome Abnormalities: A Cohort Study. Edinburgh: University of Edinburgh, 1996, pp 62-68.

83 Warwick MM: Discussion; in Warwick MM (ed): Brain Morphology and Personality Characteristics of Subjects with Sex Chromosome Anomalies and Matched Controls. Edinburgh: University of Edinburgh, 1999, pp 75-105.

84 Harmon RJ, Bender BG, Linden MG, Robinson A: Transition from adolescence to early adulthood: adaptation and psychiatric status of women with 47,XXX. J Am Acad Child Adolesc Psychiatry 1998; 37: 286-291.

85 Robinson A, Bender BG, Linden MG: Prognosis of prenatally diagnosed children with sex chromosome aneuploidy. Am J Med Genet 1992; 44: 365-368.

86 Tsuang MT: Sex chromatin anomaly in Chinese females: psychiatric characteristics of XXX. Br J Psychiatry 1974; 124: 299-305.

87 Oduncu FS: The role of non-directiveness in genetic counseling. Med Health Care Philos 2002; 5: 53-63.

88 Abramsky L, Hall S, Levitan J, Marteau TM: What parents are told after prenatal diagnosis of a sex chromosome abnormality: interview and questionnaire study. Br Med J 2001; 322: 463-466.

89 Farsides B, Williams C, Alderson P: Aiming towards 'moral equilibrium': health care professionals' views on working within the morally contested field of antenatal screening. J Med Ethics 2004; 30: 505-509.

90 Forrester MB, Merz RD: Pregnancy outcome and prenatal diagnosis of sex chromosome abnormalities in Hawaii, 1986-1999. Am J Med Genet A 2003; 119: 305-310.

91 Nagel HT, Knegt AC, Kloosterman MD, Wildschut HI, Leschot NJ, Vandenbussche FP: [Invasive prenatal diagnosis in the Netherlands, 1991-2000: number of procedures, indications and abnormal results detected]. Ned Tijdschr Geneeskd 2004; 148: 1538-1543.

92 De Vigan C, Baena N, Cariati E, Clementi M, Stoll C: Contribution of ultrasonographic examination to the prenatal detection of chromosomal abnormalities in 19 centres across Europe. Ann Genet 2001; 44: 209-217.

93 Marteau T, Drake H, Reid M et al: Counselling following diagnosis of fetal abnormality: a comparison between German, Portuguese and UK geneticists. Eur J Hum Gene 1994; 2: 96-102.

94 Wertz DC, Fletcher JC: Genetics and Ethics in Global Perspective. Dordrecht: Kluwer Academic Publishers, 2004.

95 Sagi M, Meiner V, Reshef N, Dagan J, Zlotogora J: Prenatal diagnosis of sex chromosome aneuploidy: possible reasons for high rates of pregnancy termination. Prenat Diagn 2001; 21: 461-465.

96 Meschede D, Louwen F, Nippert I, Holzgreve W, Miny P, Horst J: Low rates of pregnancy termination for prenatally diagnosed Klinefelter syndrome and other sex chromosome polysomies. Am J Med Genet 1998; 80: 330-334.

97 Hashiloni-Dolev Y: Genetic counseling for sex chromosome anomalies (SCAs) in Israel and Germany: assessing medical risks according to the importance of fertility in two cultures. Med Anthropol Q 2006; 20: 469-486.

98 Robinson A, Bender BG, Linden MG: Decisions following the intrauterine diagnosis of sex chromosome aneuploidy. Am J Med Genet 1989; 34: 552-554.

99 Linden MG, Bender BG, Robinson A: Intrauterine diagnosis of sex chromosome aneuploidy. Obstet Gynecol 1996; 87: 468-475.

100 Vaknin Z, Reish O, Ben-Ami I, Heyman E, Herman A, Maymon R: Prenatal diagnosis of sex chromosome abnormalities: the 8-year experience of a single medical center. Fetal Diagn Ther 2008; 23: 76-81.

101 Shaw SW, Chueh HY, Chang SD, Cheng PJ, Hsieh TT, Soong YK: Parental decisions regarding prenatally detected fetal sex chromosomal abnormality and the impact of genetic counselling: An analysis of 57 cases in Taiwan. Aust N Z J Obstet Gynaecol 2008; 48: 155-159.

102 Chiat S, Roy P: Early phonological and sociocognitive skills as predictors of later language and social communication outcomes. J Child Psychol Psychiatry 2008; 49: 635-645.

103 Lanfranco F, Kamischke A, Zitzmann M, Nieschlag E: Klinefelter's syndrome. Lancet 2004; 364: 273-283.
104 Stahl SM: Sex and psychopharmacology: is natural estrogen a psychotropic drug in women? Arch Gen Psychiatry 2001; 58: 537-538.

105 Amin Z, Canli T, Epperson CN: Effect of estrogen-serotonin interactions on mood and cognition. Behav Cogn Neurosci Rev 2005; 4: 43-58.

106 Walf AA, Frye CA: A review and update of mechanisms of estrogen in the hippocampus and amygdala for anxiety and depression behavior. Neuropsychopharmacology 2006; 31: 1097-1111.

107 Kulkarni J, de Castella A, Fitzgerald PB et al: Estrogen in severe mental illness: a potential new treatment approach. Arch Gen Psychiatry 2008; 65: 955-960.

108 Frances AJ: Diagnostic and Statistical Manual of Mental Disorders, DSM-IV-TR, 4th edn (text revision edn) Washington, DC: American Psychiatric Association, 2000.

109 Thewissen V, Myin-Germeys I, Bentall R, de Graaf R, Vollebergh W, van Os J: Instability in self-esteem and paranoia in a general population sample. Soc Psychiatry Psychiatr Epidemiol 2007; 42: 1-5.

110 Thewissen V, Bentall RP, Lecomte T, van Os J, Myin-Germeys I: Fluctuations in self-esteem and paranoia in the context of daily life. J Abnorm Psychol 2008; 117: 143-153.

111 Crow TJ: Sex chromosomes and psychosis. The case for a pseudoautosomal locus. Br J Psychiatry 1988; 153: 675-683.

112 DeLisi LE, Friedrich U, Wahlstrom J et al: Schizophrenia and sex chromosome anomalies. Schizophr Bull 1994; 20: 495-505.

113 Penrose LS: Finger-print pattern and the sex chromosomes. Lancet 1967; 289: 298-300.

114 Barlow PW: The influence of inactive chromosomes on human development. Anomalous sex chromosome complements and the phenotype. Humangenetik 1973; 17: 105-136.

115 Barlow PW: X-chromosomes and human development. Dev Med Child Neurol 1973; 15: 205-208.

116 Netley CT, Rovet J: Verbal deficits in children with 47,XXY and 47,XXX karyotypes: a descriptive and experimental study. Brain Lang 1982; 17: 58-72.

117 Barlow PW: Differential cell division in human X chromosome mosaics. Humangenetik 1972; 14: 122-127.

118 Kaback MM, Bernstein LH: Biologic studies of trisomic cells grown in vitro. Ann NY Acad Sci 1970; 171: 526-536.

119 Torres EM, Sokolsky T, Tucker CM et al: Effects of aneuploidy on cellular physiology and cell division in haploid yeast. Science 2007; 317: 916-924.

120 Francis D, Davies MS, Barlow PW: A strong nucleotypic effect on the cell cycle regardless of ploidy level. Ann Bot (Lond) 2008; 101: 747-757.

121 Eisch AJ: Adult neurogenesis: implications for psychiatry. Prog Brain Res 2002; 138 : 315-342.

122 McCurdy RD, Feron F, Perry $\mathrm{C}$ et al: Cell cycle alterations in biopsied olfactory neuroepithelium in schizophrenia and bipolar I disorder using cell culture and gene expression analyses. Schizophr Res 2006; 82: 163-173.

123 Dranovsky A, Hen R: DISC1 Puts the Brakes on Neurogenesis. Cell 2007; 130: 981-983.

124 Duan X, Chang JH, Ge S et al: Disrupted-in-schizophrenia 1 regulates integration of newly generated neurons in the adult brain. Cell 2007; 130: 1146-1158.

125 Chubb JE, Bradshaw NJ, Soares DC, Porteous DJ, Millar JK: The DISC locus in psychiatric illness. Mol Psychiatry 2008; 13: 36-64.

126 Zhao M, Momma S, Delfani K et al: Evidence for neurogenesis in the adult mammalian substantia nigra. Proc NatI Acad Sci USA 2003; 100: 7925-7930.

127 Kempermann G: Adult Neurogenesis; Stem Cells and Neuronal Development in the Adult Brain. New York: Oxford University Press, 2006.

128 Migeon BR: Females are MOSAICS; $X$ Inactivation and Sex Differences in Disease. New York: Oxford University Press, 2007.

129 Lyon MF: No longer 'all-or-none'. Eur J Hum Genet 2005; 13: 796-797.

130 Latham KE: $X$ chromosome imprinting and inactivation in preimplantation mammalian embryos. Trends Genet 2005; 21: 120-127.

131 Carrel L, Willard HF: X-inactivation profile reveals extensive variability in X-linked gene expression in females. Nature 2005; 434: 400-404.

132 Vawter MP, Harvey PD, DeLisi LE: Dysregulation of X-linked gene expression in Klinefelter's syndrome and association with verbal cognition. Am J Med Genet B Neuropsychiatr Genet 2007; 144: 728-734.

133 Migeon BR, Lee $\mathrm{CH}$, Chowdhury AK, Carpenter $\mathrm{H}$ : Species differences in TSIX/Tsix reveal the roles of these genes in X-chromosome inactivation. Am J Hum Genet 2002; 71: 286-293.

134 Chiurazzi P, Schwartz CE, Gecz J, Neri G: XLMR genes: update 2007. Eur J Hum Genet 2008; 16: 422-434.

135 Ruppenthal GC, Caffery SA, Goodlin BL, Sackett GP, Vigfusson NV, Peterson VG: Pigtailed macaques (Macaca nemestrina) with trisomy $\mathrm{X}$ manifest physical and mental retardation. Am J Ment Defic 1983; 87: 471-476.

136 Moreno-Millan M, Delgado Bermejo JV, Lopez Castillo G: An intersex horse with $X$ chromosome trisomy. Vet Rec 1989; 124: 169-170.

137 Endo A, Watanabe T: A case of X-trisomy in the mouse. Cytogenet Cell Genet 1989; 52: 98-99.

138 Di Meo GP, Perucatti A, Di Palo R et al: Sex chromosome abnormalities and sterility in river buffalo. Cytogenet Genome Res 2008; 120: 127-131.

139 Firth HV, Hurst JA: 47,XXX. In: Firth HV, Hurst JA, Hall JG (eds): Oxford Desk Reference Clinical Genetics. Oxford: Oxford University Press, 2005, p 494. 